\title{
Comparison of response of soybean irrigated by surface and subsurface drip irrigation method to deficit irrigation using canopy temperature under the Mediterranean conditions
}

Akdeniz koşullarında yüzey ve yüzeyaltı damla sulama yöntemi ile sulanan soya fasulyesinin sulama açığına tepkisinin taç sıcaklığı kullanılarak karşılaştırıması

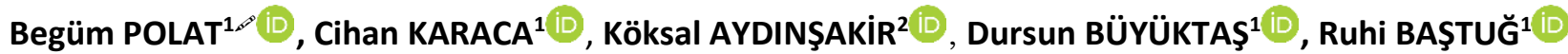 \\ ${ }^{1}$ Akdeniz University, Faculty of Agriculture, Department of Agricultural Structures and Irrigation, Antalya, Turkey. \\ ${ }^{2}$ Batı Akdeniz Agricultural Research Institute (BAARI), Antalya, Turkey.
}

MAKALE BILGISI / ARTICLE INFO

Makale tarihçesi / Article history:

DOI: $10.37908 /$ mkutbd.816447

Geliş tarihi /Received:26.10.2020

Kabul tarihi/Accepted:08.02.2021

\section{Keywords:}

Infrared thermometry, Glycine max, deficit irrigation, Antalya, semi-arid.

\footnotetext{
Corresponding author: Begüm POLAT

$\triangle$ : btekelioglu@akdeniz.edu.tr
}

\section{ÖZET / A BSTRACT}

\footnotetext{
Atıf / Citation: Polat B, Karaca C, Aydınşakir K, Büyüktaş D, Baştuğ R (2021) Comparison of response of soybean irrigated by surface and subsurface drip irrigation method to deficit irrigation using canopy temperature under the Mediterranean conditions. MKU. Tar. Bil. Derg. 26(2) : 228-237. DOI: 10.37908/mkutbd.816447
} 


\section{INTRODUCTION}

Global warming and drought is the most important environmental factor that limits plant development and reduces vegetative production in agricultural areas in Mediterranean regions. This factor also adversely affects the limited water resources of the world. In the Mediterranean Region, which is one of the most affected areas by global warming, it is aimed to reach the maximum efficiency of the use of irrigation water for improvement of agricultural production and optimization of water resources. Irrigation systems should be properly managed to achieve maximum efficiency in irrigation water use. Use of subsurface drip irrigation (SDI) method can provide an improvement in irrigation water use efficiency.

Drip irrigation method (DI) is constantly changing with the development of technology. Subsurface drip irrigation (SDI) which is a different form of drip irrigation, generally defined as the application of water below the soil surface through emitters with discharge rates in the same as drip irrigation (ASAE 2001). The SDI method directly delivers water to the root zone of the plant, so the soil surface does not wet and thus the loss of evapotranspiration is considerably reduced. As SDI reduces surface evaporation, it saves water and at the same time increases the yield and quality of the plant by reducing the risk of weeds and diseases (Camp 1998; Lamm et al. 2003; Payero et al. 2005; Reich et al. 2009). These properties make advantageous to use SDI. SDI applications were found suitable for a large number of crops (Camp 1998). Researches on crops to evaluate the effect of SDI on yield showed that crop yield obtained from SDI method were equal or greater than crop yield obtained from DI method (Phene et al. 1987; Camp 1998). The advantages and disadvantages of using subsurface drip irrigation should be investigated in different plants and climatic conditions, their effects on yield and their contribution to water saving by applying deficit irrigation should be examined.

Evaluating the water situation in the plant is important both for the yield of the crop and for the efficient use of water resources in agriculture. Furthermore, it is advantageous to know the crop water status for irrigation scheduling, since crops respond to both the soil and aerial environment (Yazar et al. 1999). Infrared thermometers are fast and reliable tools that measure the canopy temperature of the crop and provide information on the water status (Hatfield 1990). When a plant is under stress due to lack of water, it tends to close the stomata to decrease transpiration leading to an increase in canopy temperature. Canopy temperature, under both water stress and no stress conditions, may provide information on crop water status and proper irrigation management (Idso et al. 1981; Jackson et al. 1981; Hatfield 1990).

Soybean, which is one of the most important legumes, contains a high percentage of protein and increase soil characteristics through its ability of root nodulation. In Turkey, soybean planted area and production are 352947 da and 150000 tons, respectively (TUiK 2020). Due to insufficient soybean production, thousands of tons of oil and oil seeds are imported every year. In 2016, about 2.3 million tons of soybean and 10 thousand tons of soybean oil were imported (Kıllı and Beycioğlu 2019). Quality of soybean production should be improved and different management technologies should be developed. Irrigation scheduling is the most important application that increases the yield and quality of plants. Canopy temperature, measured by an infrared thermometer, is an important parameter used in the management of irrigation water.

Nielsen (1990) used the canopy temperature values obtained by using an infrared thermometer for irrigation scheduling for the soybean plant. Tekelioğlu et al. (2017) demonstrated that infrared thermometer can be used to schedule irrigation of the soybean plant under Mediterranean (Antalya) conditions of Turkey. Evett et al. (2000) compared threshold-time canopy temperature combinations for irrigation scheduling with manually operated irrigation scheduling using three irrigation rates $(33 \%, 67 \%$ and $100 \%$ of meeting full crop ET) in corn and soybean. They concluded that threshold canopy temperature treatments have generally higher or similar yield compared to manually operated irrigation treatment.

Although there are many studies evaluating the effects of DI method on the characteristics of soybean (Evett et al. 2000; Payero and Irmak 2006; Candogan et al. 2013; Irmak et al. 2014; Ospanbayev et al. 2017; Tekelioğlu et al. 2017) studies on the use of SDI method is lacking. These two methods should be compared with each other to determine which irrigation method increases yield and quality and saves water. These methods should also be evaluated in terms of canopy temperature for possible use in crop water stress studies.

The aim of this study was to compare the effects of surface drip (DI) and subsurface drip irrigation (SDI) methods on canopy temperature measured with infrared thermometer in soybean grown at Batı Akdeniz Agricultural Research Institute (BAARI), Antalya, Turkey.

\section{MATERIALS and METHODS}

The study was carried out between August and October 2017 at Batı Akdeniz Agricultural Research Institute 
(BAARI), Antalya, Turkey. The research station was located at a latitude of $36^{\circ} 52^{\prime} \mathrm{N}$, a longitude of $30^{\circ} 50^{\prime}$ $\mathrm{E}$, and an altitude of $28 \mathrm{~m}$. The physical and chemical characteristics of soil were presented in Table 1. Average meteorological data during the experimental period and long-term measurements in Antalya were given in Table 2.

Table 1. Physical and chemical characteristics of the soil

\begin{tabular}{|c|c|c|c|c|c|c|c|c|c|c|}
\hline $\begin{array}{l}\text { Depth } \\
\text { (cm) }\end{array}$ & $\begin{array}{l}\text { Sand } \\
\text { (\%) }\end{array}$ & $\begin{array}{l}\text { Clay } \\
\text { (\%) }\end{array}$ & $\begin{array}{l}\text { Silt } \\
\text { (\%) }\end{array}$ & Texture & $\begin{array}{c}\mathrm{CaCO}_{3} \\
(\%)\end{array}$ & $\begin{array}{c}E C \\
\left(d S ~^{-1}\right)\end{array}$ & pH & $\begin{array}{c}\text { Field } \\
\text { Capacity } \\
\left(\mathrm{g} \mathrm{g}^{-1}\right)\end{array}$ & $\begin{array}{l}\text { Permanent } \\
\text { Wilting Point } \\
\qquad\left(\mathrm{g} \mathrm{g}^{-1}\right)\end{array}$ & $\begin{array}{c}\text { Bulk } \\
\text { Density } \\
\left(\mathrm{g} \mathrm{cm}^{-3}\right)\end{array}$ \\
\hline $0-30$ & 13 & 44 & 43 & $\begin{array}{l}\text { Clay } \\
\text { Loam }\end{array}$ & 25.6 & 0.103 & 8.3 & 0.23 & 0.13 & 1.31 \\
\hline $30-60$ & 13 & 40 & 47 & $\begin{array}{l}\text { Clay } \\
\text { Loam }\end{array}$ & 24.8 & 0.108 & 8.3 & 0.24 & 0.11 & 1.38 \\
\hline $60-90$ & 13 & 38 & 49 & Loam & 23.7 & 0.156 & 8.4 & 0.22 & 0.12 & 1.43 \\
\hline
\end{tabular}

Table 2. Monthly mean climatic data throughout the growing season of the soybean at the experimental site for longterm and the experimental year

\begin{tabular}{|c|c|c|c|c|c|c|}
\hline Years & Months & $\begin{array}{c}\text { Temperature } \\
\left({ }^{\circ} \mathrm{C}\right)\end{array}$ & $\begin{array}{c}\text { Rainfall } \\
(\mathrm{mm})\end{array}$ & $\begin{array}{c}\text { Evaporation } \\
(\mathrm{mm})\end{array}$ & $\begin{array}{l}\text { Wind } \\
\left(\mathrm{m} \mathrm{sn}^{-1}\right)\end{array}$ & $\begin{array}{l}\text { Relative humidity } \\
\text { (\%) }\end{array}$ \\
\hline \multirow{5}{*}{$1954-2015$} & June & 25.5 & 7.6 & 177.5 & 1.9 & 55.2 \\
\hline & July & 28.3 & 3.4 & 195.5 & 1.9 & 54.3 \\
\hline & Aug. & 28.2 & 1.8 & 172.4 & 1.7 & 56.7 \\
\hline & Sep. & 24.4 & 12.3 & 134.4 & 1.8 & 58.8 \\
\hline & Oct. & 20.0 & 80.1 & 150.6 & 2.0 & 61.0 \\
\hline \multirow{5}{*}{2017} & June & 26.3 & - & 125.6 & 1.8 & 63.1 \\
\hline & July & 30.5 & - & 161.1 & 1.9 & 57.4 \\
\hline & Aug. & 29.0 & - & 155.2 & 1.9 & 64.4 \\
\hline & Sep. & 26.9 & - & 137.3 & 1.8 & 62.8 \\
\hline & Oct. & 22.2 & 12.6 & 111.5 & 1.7 & 53.2 \\
\hline
\end{tabular}

The salinity of the water used in the irrigation was 0.561 $\mathrm{dS} \mathrm{m}^{-1}$ and $\mathrm{pH}$ 7.3. ATAEM-7 cultivar was used as the crop material in the study. Soybean seeds were planted $70 \mathrm{~cm}$ apart between rows, $10 \mathrm{~cm}$ in rows at a depth of $5-6 \mathrm{~cm}$ in 14 July 2017. In sub-surface drip irrigation, laterals were placed at a depth of $40 \mathrm{~cm}$ below the soil surface. The canopy temperatures were measured daily by an infrared thermometer (Spectrum Technologies Inc.) at a field of view of 45ㅇ between 12:00 and 15:00 hours, from four directions (East, West, North, and South) in each plot. In the experiment, a total of twelve irrigation applications were made based on the treatments, seven of which were in the period of canopy temperature measurement. In order to determine the crop canopy temperatures properly, it was started to measure when the plant height reached $100 \mathrm{~cm}$ for full irrigation treatment. In order to determine the effect of different irrigation methods on the canopy temperature of soybean, canopy temperature measurements were made eleven times during the growing season, at the beginning of irrigation, at the end of irrigation, and in the middle of two irrigation applications.

Table 3. Irrigation methods and treatments used in the study

\begin{tabular}{|c|c|c|}
\hline \multicolumn{2}{|c|}{ Irrigation Methods } & $\begin{array}{c}\text { Irrigation } \\
\text { Treatments }\end{array}$ \\
\hline \multirow{6}{*}{ Irrigated } & \multirow{3}{*}{$\begin{array}{l}\text { Subsurface drip } \\
\text { irrigation (SDI) }\end{array}$} & SDI-I 100 \\
\hline & & $\mathrm{SDI}_{80}$ \\
\hline & & SDI-I 60 \\
\hline & \multirow{3}{*}{ Surface drip (DI)) } & DI-I 100 \\
\hline & & $\mathrm{DI}-\mathrm{I}_{80}$ \\
\hline & & DI-I 60 \\
\hline Rainfed & & Rainfed $\left(I_{0}\right)$ \\
\hline
\end{tabular}

The study was designed in randomized complete block design to include two irrigation methods (subsurface drip irrigation (SDI), (surface drip (DI)) and four different irrigation treatments $\left(I_{0}, I_{60}, I_{80}\right.$ and $\left.I_{100}\right)$ in three replications. The irrigation treatments were formed with 
two irrigation methods (DI and SDI) and four irrigation water levels as $0 \%\left(\right.$ rainfed $\left.\left(I_{0}\right)\right), 60 \%\left(I_{60}\right), 80 \%\left(I_{80}\right)$ and $100 \%$ (full irrigation $\left(I_{100}\right)$. The full irrigation treatment was performed when $30 \%$ of the available water holding capacity in the $0-90 \mathrm{~cm}$ soil profile was depleted, while the deficit irrigation treatments were applied at $80 \%\left(\mathrm{I}_{80}\right)$ and $60 \%\left(I_{60}\right)$ of the full irrigation treatment. Irrigation methods and treatments were shown in Table 3.

The crops harvested from the middle two rows of each plot were passed through a threshing machine, grains were separated, dried and cleaned. The weights were determined and grain yield for decare was calculated according to the yield. Variance analysis was applied to evaluate yield statistically and Duncan Multiple Comparison Test was used to compare the means
(Gomez and Gomez, 1984). The relationships between plant canopy temperatures and yield, applied irrigation water and evapotranspiration were determined with the help of a nonlinear exponential relationship. In addition, the correlation test was conducted to determine the direction of the relationship between these parameters.

\section{RESULTS and DISCUSSION}

Soil water content changes in the treatments were determined before each irrigation with the gravimetric method in soil profile between $0-90 \mathrm{~cm}$. Changes in soil water content measured throughout the season for SDI and DI were given in Figures 1 and 2, respectively.

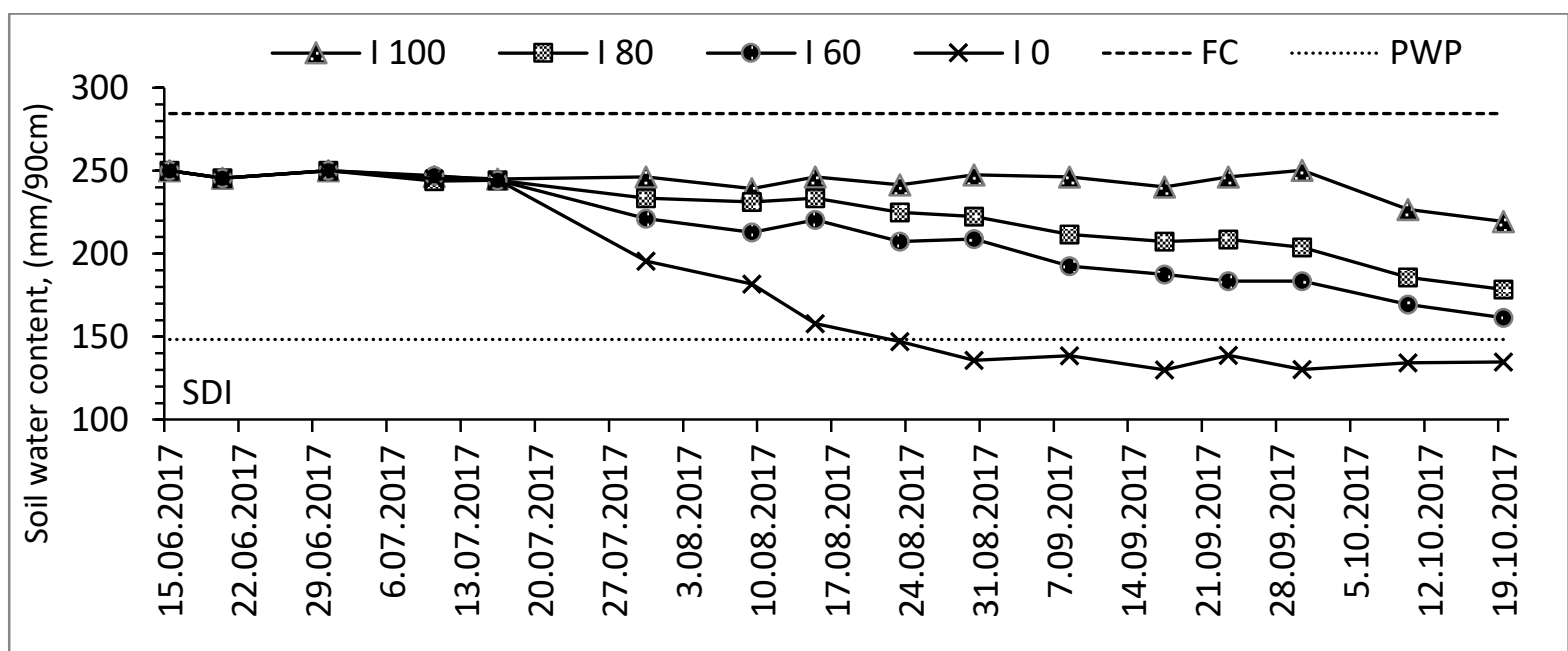

Figure 1. Change of soil water content in subsurface drip irrigation treatments (SDI) during the experimental period.

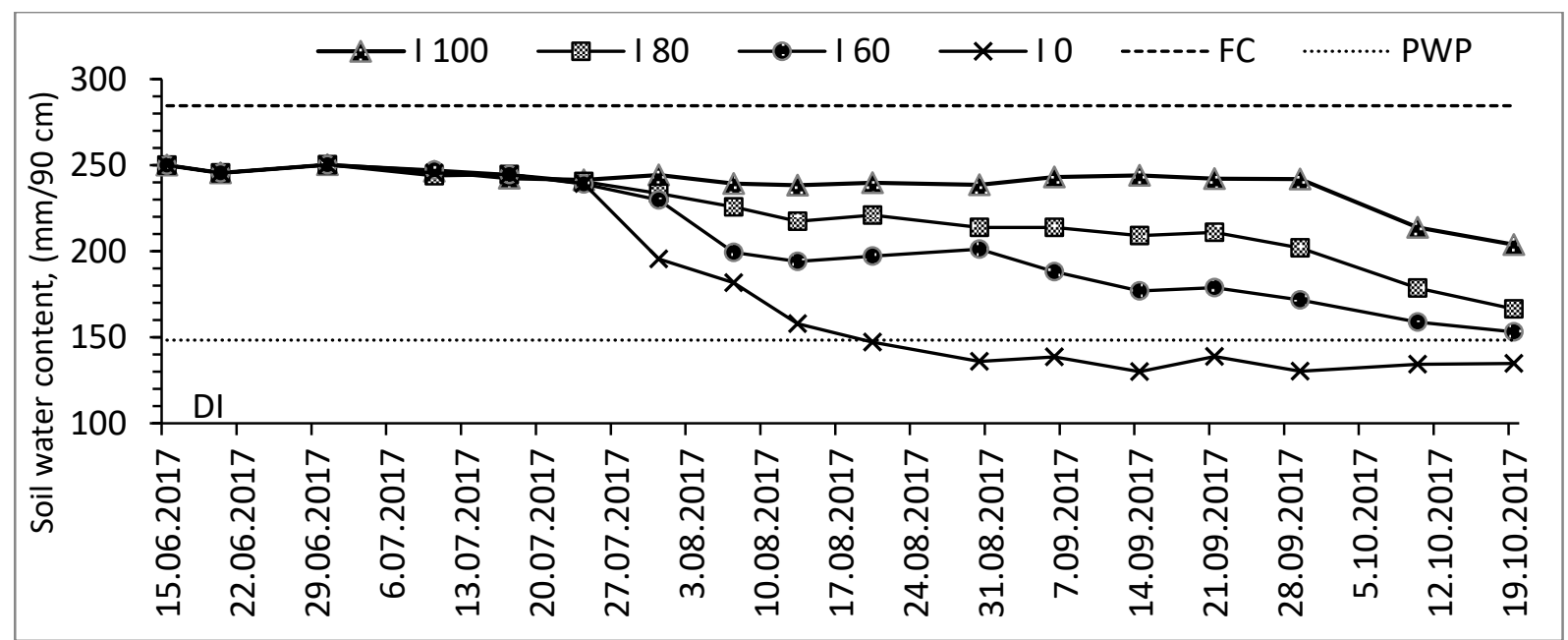

Figure 2. Change of soil water content in surface drip irrigation treatments (DI) during the experimental period.

When figures 1 and 2 were examined, it was found that the soil moisture content fluctuates between field capacity and wilting point in all irrigation treatments except rainfed treatment $\left(I_{0}\right)$. At the same time, as the amount of water applied increases in both figures, the soil moisture content also increases. Water budget parameters in the SDI and DI treatments of soybeans were given in Table 3. From Table 3, it was understood 
that seasonal ET values in $\mathrm{I}_{0}, \mathrm{DI}-\mathrm{I}_{60}, \mathrm{DI}-\mathrm{I}_{80}, \mathrm{DI}-\mathrm{I}_{100}, \mathrm{SDI}-\mathrm{I}_{60}$, SDI-I 80 , and SDI-I 100 treatments were 164.3, 461.6, 544.4, $611.7,410.7,481.3$ and $527.3 \mathrm{~mm}$, respectively.

Table 3. Water budget parameters in the SDI and DI treatments of soybeans

\begin{tabular}{cccccc}
\hline Treatments & $\begin{array}{c}\mathrm{I} \\
(\mathrm{mm})\end{array}$ & $\begin{array}{c}\mathrm{P} \\
(\mathrm{mm})\end{array}$ & $\begin{array}{c}\Delta \mathrm{S} \\
(\mathrm{mm})\end{array}$ & $\begin{array}{c}\mathrm{DP} \\
(\mathrm{mm})\end{array}$ & $\begin{array}{c}\mathrm{ET} \\
(\mathrm{mm})\end{array}$ \\
\hline $\mathrm{I}_{0}$ & 50.0 & 12.6 & 101.7 & 0.0 & 164.3 \\
$\mathrm{DI} \mathrm{I}_{60}$ & 357.7 & 12.6 & 91.3 & 0.0 & 461.6 \\
$\mathrm{DI}_{80}$ & 460.3 & 12.6 & 71.5 & 0.0 & 544.4 \\
$\mathrm{DI}_{8} \mathrm{I}_{100}$ & 562.8 & 12.6 & 36.3 & 0.0 & 611.7 \\
\hline $\mathrm{SDI}_{60}$ & 310.7 & 12.6 & 87.4 & 0.0 & 410.7 \\
$\mathrm{SDI}_{80}$ & 397.6 & 12.6 & 71.1 & 0.0 & 481.3 \\
SDI-I $_{100}$ & 484.5 & 12.6 & 30.1 & 0.0 & 527.3 \\
\hline
\end{tabular}

When comparing all ET values obtained from the different irrigation methods of the same irrigation treatments, the SDI method was found to be lower than the DI method. The results obtained from $I_{100}$ (Control) showed that approximately $78.3 \mathrm{~mm}$ of water was saved by using the SDI method in irrigation.

Many studies were conducted to determine the ET values of the soybean plant in Turkey. It was reported that the ET value of soybeans varies between 355 and $809 \mathrm{~mm}$ in Bursa by Candoğan and Yazgan (2016) and between 453.0 and $805.0 \mathrm{~mm}$ in Urfa by Yazar et al. (1991). In addition, Ozkara (1991) found that the soybean ET value was 444.9 in Menemen. The results obtained from this study were in good agreement with the literature.

Change of canopy temperature in DI and SDI treatments during the experimental period were given in Figure 3, 4 and 5 .

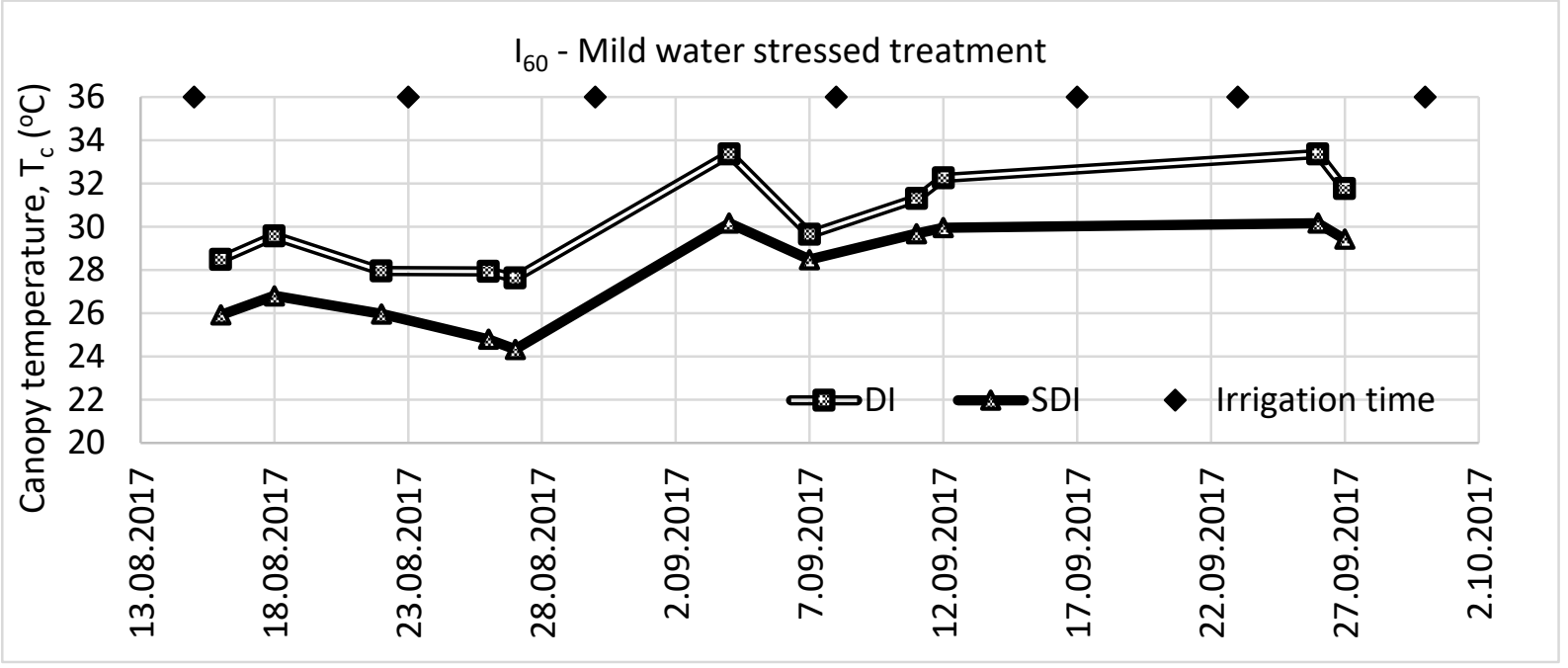

Figure 3. Change of canopy temperature in DI-I 60 and SDI-I ${ }_{60}$ treatments

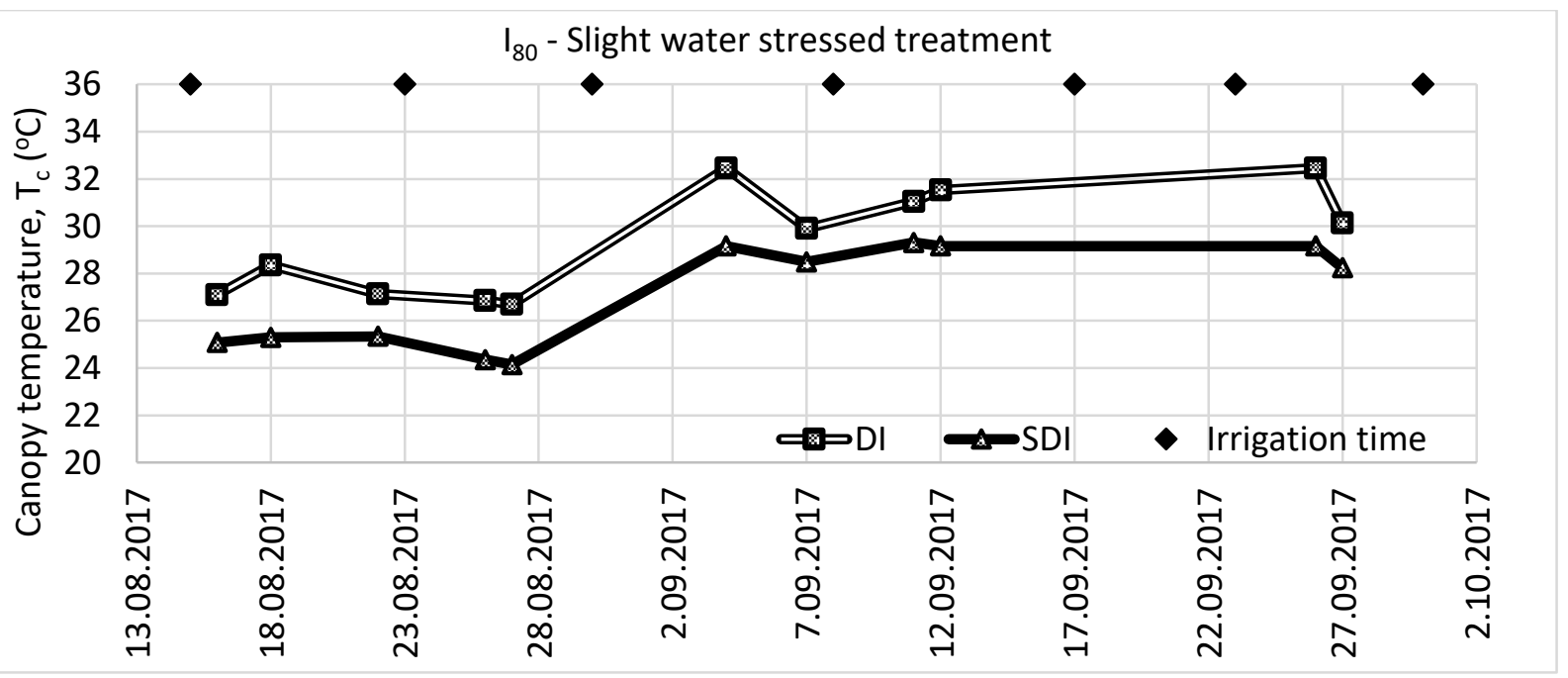

Figure 4. Change of canopy temperature in $\mathrm{DI}-\mathrm{I}_{80}$ and $\mathrm{SDI}-\mathrm{I}_{80}$ treatments 
When the figures were examined, it was seen that the canopy temperatures of the crops irrigated with the SDI method were approximately $2.5{ }^{\circ} \mathrm{C}$ lower than $\mathrm{DI}$ method in all treatments throughout the season. This result indicated that the soybean plant irrigated with the SDI method was less stressful than irrigated with the DI method. When the interaction of the treatments was examined the highest canopy temperature was obtained from the $\mathrm{DI}^{-I_{60}}$ treatment while the lowest canopy temperature was obtained from $\mathrm{SDI}_{80}$ and $\mathrm{SDI}-\mathrm{I}_{100}$. During the season, the average of canopy temperatures obtained from SDI was $27^{\circ} \mathrm{C}$ while the average of canopy temperatures obtained from DI application was calculated as $29^{\circ} \mathrm{C}$. Evett et al. (2000) used wired, fixed IRT measuring the canopy temperatures in soybean and maize plants irrigated with surface and subsurface drip irrigation system. They reported that the optimum canopy temperature threshold for soybean was determined to be $27^{\circ} \mathrm{C}$, although they also evaluated the threshold temperature of $29^{\circ} \mathrm{C}$ for soybean. Anda et al. (2019) studied on two different soybean varieties to assess evapotranspiration rates, canopy temperatures $\left(T_{c}\right)$, and crop water stress index (CWSI) using three levels of water supply (unlimited water, $50 \%$ of water requirement in atmometer, and rainfed conditions). During the season, they calculated the canopy temperatures obtained from unlimited water treatment as an average of $28.5 \pm 1.97$ and $28.3 \pm 2.23$ for two different varieties. In our study, the average canopy temperature from SDI- $\mathrm{I}_{100}$ (full irrigation) and $\mathrm{DI}^{-\mathrm{I}_{100}}$ was $26.84^{\circ} \mathrm{C}$ and, $29.16{ }^{\circ} \mathrm{C}$, respectively. When we compare the canopy temperatures of stress-free treatments from the two studies, we can say that the results are similar. The effect of different irrigation methods and irrigation treatments on yield $\left(\mathrm{kg} \mathrm{da}^{-1}\right)$ was given in Table 4.

Yield values ranged from 225.8 to $632.6 \mathrm{~kg} \mathrm{da}^{-1}$. The mean yield values obtained from the SDI method (439.1 $\mathrm{kg} \mathrm{da}^{-1}$ ) were statistically higher than DI method (395.2 $\left.\mathrm{kg} \mathrm{da}^{-1}\right)$. In addition, the yield was increased depending on the irrigation water applied in both irrigation methods. When the interaction between different irrigation methods and irrigation treatments was examined, there was no statistically significant difference. The highest and lowest yield was obtained in the SDI- $I_{100}\left(632.6 \mathrm{~kg} \mathrm{da}^{-1}\right)$ and, for DI and SDI, Io (225.8 $\mathrm{kg} \mathrm{da}^{-1}$ ) treatments, respectively.

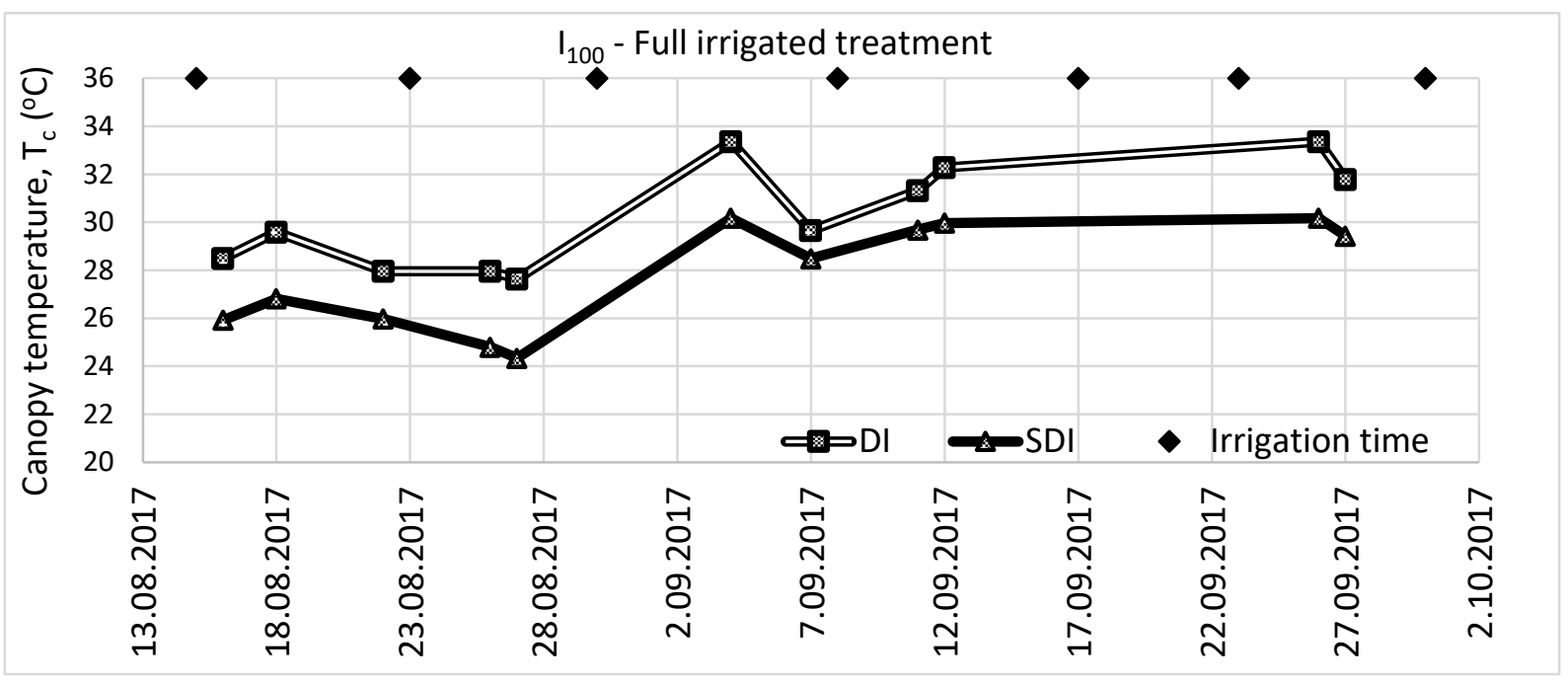

Figure 5. Change of canopy temperature in $\mathrm{DI}-\mathrm{I}_{100}$ and $\mathrm{SDI}-\mathrm{I}_{100}$ treatments

Table 4. The effect of different irrigation methods and irrigation treatments on yield $\left(\mathrm{kg} \mathrm{da}^{-1}\right)$

\begin{tabular}{|c|c|c|c|c|c|}
\hline \multirow{2}{*}{ Irrigation methods } & \multicolumn{4}{|c|}{ Irrigation treatments } & $\begin{array}{c}\text { Mean of } \\
\text { irrigation } \\
\text { methods }\end{array}$ \\
\cline { 2 - 6 } & $I_{0}$ & $I_{60}$ & $I_{80}$ & 560.5 & $395.2 \mathrm{~b}$ \\
\hline DI & 225.8 & 314.9 & 479.5 & 632.6 & $439.1 \mathrm{a}$ \\
\hline $\begin{array}{c}\text { Mean of irrigation } \\
\text { treatments }\end{array}$ & 225.8 & 389.9 & 507.9 & $596.5 \mathrm{~A}$ & \\
\hline Significance level & $225.8 \mathrm{D}$ & $352.4 \mathrm{C}$ & $493.7 \mathrm{~B}$ & ITx IM: ns \\
\hline
\end{tabular}

The capital letters showed the comparison of the averages given along the horizontal (along the row) and the small letters were given in vertical (along the column) at the $5 \%$ significance level according to the LSD test. **: \%1 significance level of probability; ns: not significant. 
These results show that the SDI method compared to the DI method increases the yield of the soybean. Candoğan and Yazgan (2016) investigated the effects of full and deficit irrigation on the yield and quality of soybeans applied in different growth stages in humid climatic conditions over a two-year period. Researchers obtained the highest seed yield $\left(400.4 \mathrm{~kg} \mathrm{da}^{-1}\right)$ from the treatment of full irrigation (based on the replenishment of $100 \%$ of soil water depletion from a soil depth of $90 \mathrm{~cm}$ at 7-day intervals throughout the development period) and the lowest yield $\left(197.4 \mathrm{~kg} \mathrm{da}^{-1}\right)$ from the rainfed treatment. Tekelioğlu et al. (2017) investigated the crop water stress index method which used infrared thermometry (IRT) to schedule irrigations of soybeans irrigated with drip irrigation. For this purpose, they obtained various data from six different irrigation treatments $(0,0.25$, $0.50,0.75,1.00$ (full irrigation), 1.25 of the cumulative evaporation in Class A pan is $25 \pm 5 \mathrm{~mm}$ ). They reported that the highest yield from the treatments of 0.75 (359.11 kg da-1), 1.00 (410.6 kg da-1), 1.25 (475.90 kg da$\left.{ }^{1}\right)$, but they did not find a statistically significant difference among them. Evett et al. (2000) tested a system that uses four time - temperature threshold combinations, and these were compared to manually irrigated plots where three irrigation rates $(33 \%, 67 \%$ and $100 \%$ of meeting full crop ET) were used. They reported that soybean threshold temperatures were 27 ${ }^{\circ} \mathrm{C}$ and $29^{\circ} \mathrm{C}$, and threshold times were 256 and $171 \mathrm{~min}$. All IRT treatments in first year yielded more $(0.402$ to $0.432 \mathrm{~kg} \mathrm{~m}^{-2}$ ) than manual ones ( 0.328 to $0.401 \mathrm{~kg} \mathrm{~m}^{-2}$ ). They also emphasized that the yield stability for $27^{\circ} \mathrm{C}$ IRT treatments was higher than $100 \%$ treatment. When the yield values and canopy temperatures were evaluated together, it was determined that the plants irrigated with SDI method had less water stress and more yield value. When the irrigation treatments were examined, the lowest canopy temperature was obtained from SDI$\mathrm{I}_{100}$, at the same time the highest yield was obtained from SDI- $I_{100}$. The highest canopy temperature among the irrigated treatments was obtained from the DI-I ${ }_{60}$ while the lowest yield obtained from DI-I ${ }_{60}$ treatment. In these conditions, we can say that the SDI method reduces the canopy temperature by reducing stress, which is an important factor to increase yield.
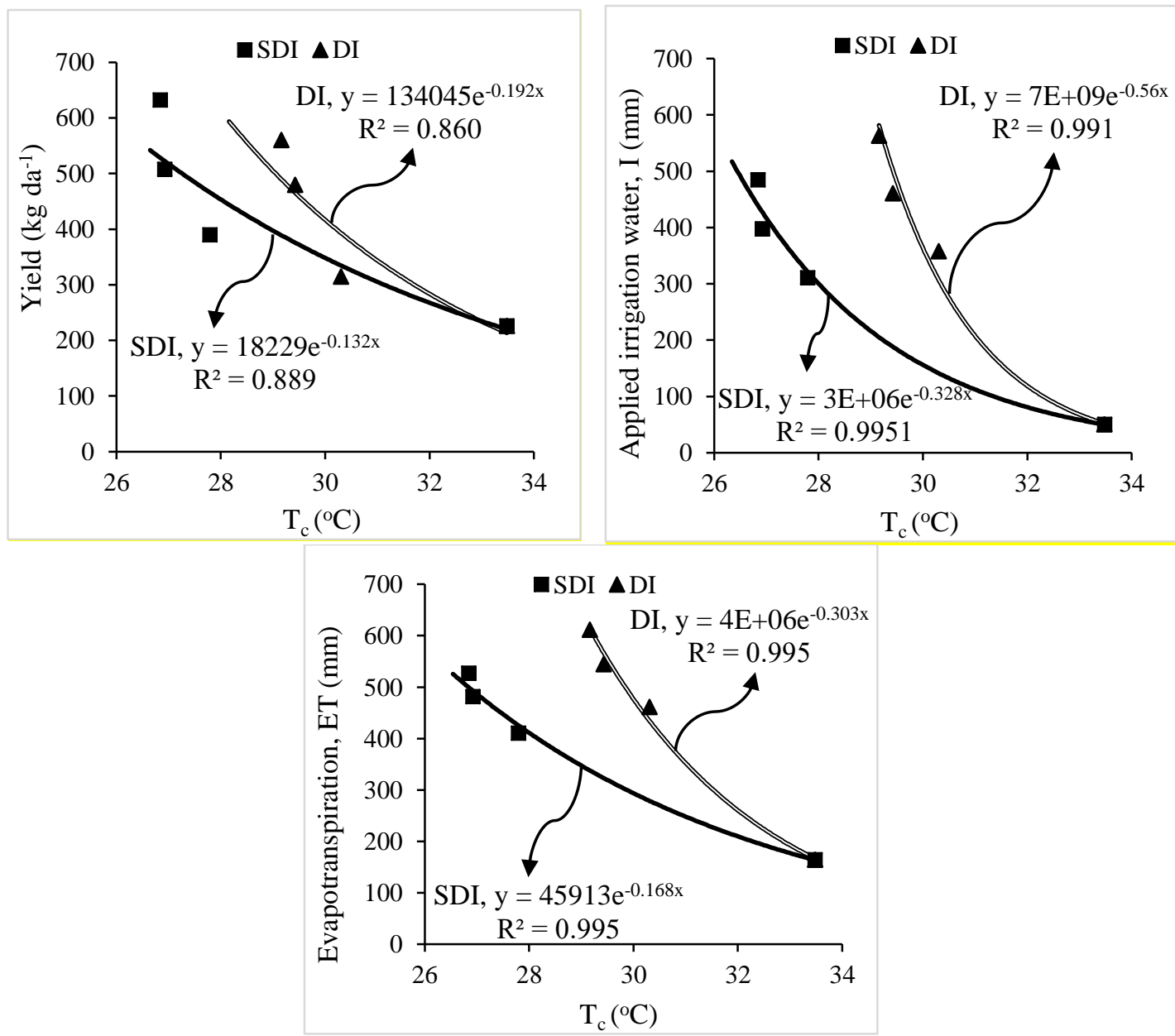

Figure 6. Relationships between mean canopy temperature and evapotranspiration, applied irrigation water and, yield parameters of soybean 
In this study, the relationships between canopy temperatures measured from different irrigation treatments and yield, evapotranspiration and applied irrigation treatment were determined. These relationships were given in Figure 6.
The correlation test was performed to determine the direction and power of the relationship between crop canopy temperature and yield, applied irrigation water (I) and evapotranspiration (ET) values. The results of the correlation test were given in Table 5.

Table 5. Correlation coefficients indicating the direction and power of the relationship between crop canopy temperature and yield, applied irrigation water (I) and evapotranspiration (ET) of soybean depending on the amount of irrigation water

\begin{tabular}{|c|c|c|}
\hline Parameters & Irrigation methods & Correlation coefficients $(r)$ \\
\hline \multirow{2}{*}{$\mathrm{T}_{\mathrm{c}}-$ Yield } & DI & -0.883 \\
\hline & SDI & -0.882 \\
\hline \multirow{2}{*}{$\mathrm{T}_{\mathrm{c}-\mathrm{I}}$} & DI & -0.986 \\
\hline & SDI & -0.964 \\
\hline \multirow{2}{*}{$\mathrm{T}_{\mathrm{c}}-\mathrm{ET}$} & DI & -0.996 \\
\hline & SDI & -0.984 \\
\hline
\end{tabular}

Although it was known that soybean yield increases significantly depending on the amount of irrigation water applied, previous studies (Egli 2008; Bao et al. 2015) showed that soybean cultivation could be also done based on rain without irrigation application. Since soybean could be grown with rainfed conditions, exponential relationships were preferred rather than linear relationships between canopy temperatures and ET, yield and I. As a matter of fact, Hou et al. (2019) reported that there was an exponential relationship between canopy temperature and yield. When Figure 6 was examined, determination coefficients showing the relationship between canopy temperature and yield in SDI and DI irrigation applications were determined as 0.89 and 0.86 , respectively. Although there was a high level of relation in both irrigation methods, a higher relation was found in SDI method. When the correlation coefficients in Table 5 were examined, it was found that there was a high inverse correlation between canopy temperature and yield in both irrigation methods. This result showed that the yield decreased as the crop canopy temperature increased due to water stress. Similarly, Hou et al. (2019) reported that the soybean crops yield decreased due to increasing canopy temperature.

When Figure 6 and Table 5 were examined, it was determined that there was a high level of exponential relationship (SDI-R ${ }^{2}: 0.995$ and DI-R ${ }^{2}$ : 0.991) and a strong negative correlation between canopy temperature and the amount of irrigation water applied (SDI-r: -0.964 and
DI-r: -0.986) for both irrigation methods in soybean. Previous studies (Demirtaş et al. 2010; Pejić et al. 2011; Irmak et al. 2014) reported that there was a significant relationship between the amount of irrigation water and drought stress in soybean. In addition, the crop canopy temperature is also widely used to calculate the crop water stress index (CWSI), which is a parameter that indicates the water status of the crop (Tekelioğlu et al. 2017; Nielsen 1990). As with I and yield, there was a high level of exponential relationship and negative correlation between ET and canopy temperature for all irrigation methods (Figure 6 and Table 5). Hou et al. (2019) stated that the magnitude of transpiration change was greater than that of the canopy temperature, both parameters were strongly interrelated with each other, but they were non-linearly correlated. When the results obtained were evaluated in general, depending on the irrigation water applied, a strong inverse relationship was determined between canopy temperatures obtained from plants and ET, yield and I, while it was not found the difference between these relationships between irrigation methods.

In conclusion, the results obtained from this study showed that plants irrigated with the SDI method compared to the DI method had lower canopy temperatures and higher yield values. In addition, when the control treatments of both irrigation methods were compared, approximately $85 \mathrm{~mm}$ of water was saved from the crops irrigated with the SDI method. Therefore, it can be concluded that SDI method uses less water than 
DI method and will contribute to optimization of water resources. Also yield values were higher in the SDI method. As a result, it was concluded that subsurface drip irrigation reduces the water stress and can save more water from available water under Mediterranean conditions and can increase the crop yield. In both irrigation methods (SDI and DI), depending on the amount of irrigation water, a high level of exponential and strong negative correlation was determined between canopy temperatures and yield, ET and, I parameters obtained from experimental treatments.

It is thought that the strong relationship between canopy temperatures and yield can be used in yield estimation by combining canopy temperatures to be measured by satellites or unmanned aerial vehicles.

\section{ÖZET}

Amaç: Su kaynaklarının sınırlı olduğu kurak ve yarı kurak bölgelerde hem tarımsal üretim hem de su kaynaklarının optimizasyonu için sulama suyu kullanım verimliliği önemli bir konudur. Bu alanların çoğunda yüzey damla sulama yöntemi (DI) yaygın olarak kullanılmakla birlikte, yüzey altı damla sulama yöntemi (SDI) son yıllarda yaygınlaşmıştır. Bu çalışmada, yüzey (DI) ve yüzey altı damla sulama (SDI) yöntemleri ile sulanan soya bitkisinin infrared termometre ile ölçülen taç sıcaklığı üzerindeki etkilerini karşılaştırmak ve soya fasulyesi üzerindeki eksik sulamaya etkilerini değerlendirmek amaçlanmıştır.

Yöntem ve Bulgular: Çalışma, iki farklı sulama yöntemi (yüzey damla sulama (DI) ve yüzey-altı damla sulama (SDI) ve dört farklı sulama düzeyinde $(\% 0, \% 60, \% 80$ ve $\% 100)$ üç tekerrürlü olarak tesadüf blokları deneme deseninde yürütülmüştür. Bitki taç sıcaklıkları, sulamadan önce ve sonra 12:00 ile 15:00 saatleri arasında kızılötesi termometre ile ölçülerek elde edilmiştir.

Genel Yorum: Sonuçlar, sezon boyunca SDI yöntemi ile sulanan bitkilerin taç sıcaklıklarının DI yöntemine göre $2.5^{\circ} \mathrm{C}$ 'a kadar daha düşük olduğunu göstermiştir. Ayrıca bu çalışmada SDI yönteminden elde edilen verim değerleri (439.1 kg da-1) DI yöntemine (395.2 kg da ${ }^{-1}$ ) göre istatistiksel olarak daha yüksek çıkmıştır. DI yöntemi ile karşılaştırıldığında, SDI yönteminde yaklaşık 78.3 mm su tasarrufu elde edilmiştir.

Çalışmanın Önemi ve Etkisi: SDI yöntemi ile sulanan soya fasulyesinin taç sıcaklıklarının DI yöntemine göre daha düşük olduğu belirlenmiştir. Ek olarak, her iki sulama yönteminde de taç sıcaklıkları ile verim, uygulanan sulama suyu ve evapotranspirasyon arasında yüksek düzeyde üstel bir ilişki ve negatif korelasyon olduğu saptanmıştır.
Anahtar Kelimeler: Infrared termometre, Glycine max, kısıntılı sulama, Antalya, yarı-kurak.

\section{ACKNOWLEDGEMENTS}

The authors are grateful to Republic of Turkey Ministry of Agriculture and Forestry General Directorate of Agricultural Research and Policies for financial support of this research (TAGEM/TSKAD/16/A13/P02/02).

\section{CONFLICT OF INTEREST}

The author declares that there is no conflict of interest in the study.

\section{AUTHOR'S CONTRIBUTIONS}

The contribution of the authors is equal.

\section{REFERENCES}

Anda A, Simon B, Soós G, Teixeira da Silva JA, Kucserka T (2019) Crop-water relation and production of two soybean varieties under different water supplies. Theoretical and Applied Climatology 137: 15151528.

ASAE (2001) Soil and water terminology. ASAE Standards 49th Ed S526.4: 903-907.

Bao Y, Hoogenboom G, McClendon RW, Paz JO (2015) Potential adaptation strategies for rainfed soybean production in the south-eastern USA under climate change based on the CSM-CROPGRO-Soybean model. Journal of Agricultural Science 153: 798824.

Camp CR (1998) Subsurface drip irrigation: A review. Trans. Am. Soc. Agric. Eng. 1353-1367.

Candogan BN, Sincik M, Buyukcangaz $H$, Demirtas C, Goksoy AT, Yazgan S (2013) Yield, quality and crop water stress index relationships for deficit-irrigated soybean [Glycine max (L.) Merr.] in sub-humid climatic conditions. Agricultural Water Management 118: 113-121.

Candoğan BN, Yazgan S (2016) Yield and quality response of soybean to full and deficit irrigation at different growth stages under sub-humid climatic conditions. Journal of Agricultural Sciences 22: 129144.

Demirtaş Ç, Yazgan S, Candogan BN, Sincik $M$, Büyükcangaz H, Göksoy AT (2010) Quality and yield response of soybean (Glycine max L. Merr.) to drought stress in subhumid environment. African Journal of BiotechnologyBiotechnology 9: 68736881.

Egli DB (2008) Soybean yield trends from 1972 to 2003 in mid-western USA. Field Crops Research 106: 53-59. 
Evett SR, Howell TA, Schneider AD, Upchurch DR, Wanjura DF (2000) Automatic drip irrigation of corn and soybean. In 'Proc. 4th Decenn. Natl. Irrig. Symp. 401-408.

Hatfield JL (1990) Measuring plant stress with an infrared thermometer. Journal of Horticultural Science 25: 1535-1538.

Hou M, Tian F, Zhang T, Huang M (2019) Evaluation of canopy temperature depression, transpiration, and canopy greenness in relation to yield of soybean at reproductive stage based on remote sensing imagery. Agricultural Water Management 222.

Idso SB, Jackson RD, Pinter PJ, Reginato RJ, Hatfield JL (1981) Normalizing the stress-degree-day parameter for environmental variability. Agricultural Meteorology 24: 45-55.

Irmak S, Specht JE, Odhiambo LO, Rees JM, Cassman KG (2014) Soybean yield, evapotranspiration, water productivity, and soil water extraction response to subsurface drip irrigation and fertigation. Transactions of the ASABE 57: 729-748.

Jackson RD, Idso SB, Reginato RJ, Pinter PJ (1981) Canopy temperature as a crop water stress indicator. Water Resources Research 17: 113-1138.

Kıllı F, Beycioğlu T (2019) Oil seeds and crude oil production in the world and Turkey, problems of oilseeds production in turkey. IJAAES International Journal of Anatolia Agricultural Engineering 1: 1733.

Lamm FR, Rogers DH, Alam M, Clark GA (2003) Design considerations for subsurface drip irrigation (SDI) Systems. Irrigation Management Series. (Kansas State University Agricultural Experiment Station and Cooperative Extension Service: Kansas).

Nielsen DC (1990) Scheduling irrigations for soybeans with the Crop Water Stress Index (CWSI). Field Crops Research 23: 103-116.

Ospanbayev ZHO, Kurmanbayeva MS, Abdukadirova ZHA, Doszhanova AS, Nazarbekova ST, Inelova ZA, Ablaikhanova NT, Kenenbayev SB, Musina AS (2017) Water use efficiency of rice and soybean under drip irrigation with mulch in the south-east of Kazakhstan. Biology Applied Ecology and Environmental Research 15: 1581-1603.
Ozkara MM (1991) Second-crop soybean menemen region water sonsumption. Menemen Agricultural Research Institute Publications, 170: 1-10.

Payero JO, Irmak S (2006) Variable upper and lower crop water stress index baselines for corn and soybean. Irrigation Science 1: 31-32.

Payero JO, Yonts CD, Irmak S, David TD (2005) Advantages and disadvantages of subsurface drip Irrigation. Historical materials from University of Nebraska-Lincoln Extension 8.

Pejić B, Maksimović L, Cimpeanu S, Bucur D, Milić S, Ćupina B (2011) Response of soybean to water stress at specific growth stages. Journal of Food, Agriculture and Environment 9: 280-284.

Phene CJ, Davis KR, Hutmacher RB, McCormick RL (1987) Advantages of Subsurface Irrigation for Processing Tomatoes. Acta Horticulturae 200: 101-113. doi:10.17660/actahortic.1987.200.9.

Reich D, Godin R, Chavez JL, Broner I (2009) Subsurface drip irrigation-Crop Series No. 4.716. (Colorado State University Extension).

Tekelioğlu B, Büyüktaş D, Baştuğ R, Karaca C, Aydinşakir K, Dinç N (2017) Use of crop water stress index for irrigation scheduling of soybean in Mediterranean conditions. Journal of Experimental Agriculture International 18: 1-8.

TUiK (2020) Bitkisel Üretim İstatistikleri-Tarım Alanları. (Ankara) http://tuik.gov.tr/PreTablo.do?alt id=1001.

Yazar A, Howell TA, Dusek DA, Copeland KS (1999) Evaluation of crop water stress index for LEPA irrigated corn. Irrigation Science 18: 171-180.

Yazar A, Oğuzer V, Tülücü K, Arığlu H, Gençoğlan C, Dıker K (1991) Harran Ovası koşullarında açık su yüzeyi (Class A Pan) buharlaşmasından yararlanarak ikinci ürün soya için sulama programlarının geliştirilmesi. GAP Kalkınma idaresi Başkanlığı Kesin Sonuç Raporu, P: 52. 